\title{
MANUSIA SEBAGAI MAKHLUK PEDAGOGIK: Pandangan Islam dan Barat
}

\author{
Oleh: Moh. Ibnu Sulaiman Slamet ${ }^{*}$
}

\begin{abstract}
There are some schools in education such as; Pessimism, Optimism, Convergence, and Islam has view point that man has potential to be educated (Homo Educandum), the talent and environment constitute two convergence lines strive one focus, that is the man development, besides that as creature who can be educated, the man also needs education in order to develop himself. Because, as human being, man is substantially has capability to know the highest level, at once place them as social creature and cultural one that his growing and developing at culture totally, including education and also as human being, man has rational capability, from rational capability the man can study fro what is seen them. The man with this potential can develop himself as caliph who has some excellences from another creature.
\end{abstract}

KEYWORDS: Manusia, pendidikan, khalifah, keunggulan

MANUSIA sebagai yang diisyaratkan Alquran, lahir tanpa memiliki pengetahuan apapun. ${ }^{1}$ Namun, pada diri manusia terdapat sejumlah potensi yang memungkinkannya memiliki pengetahuan setelah beradaptasi dengan lingkungan sekitarnya. Bahkan menurut ajaran Islam potensipotensi tersebut menyebabkan manusia memiliki kewajiban untuk harus berpengetahuan, bahkan harus cerdas, karena untuk mencapai atau memiliki keunggulan komparatif (kebahagiaan) di dunia maupun di akhirat, manusia harus berilmu.

Pilihan untuk berpengetahuan atau cerdas biasanya disinergikan dengan pendidikan, yang telah berlangsung sepanjang umur manusia, pada masyarakat primitif maupun masyarakat modern, dan akan tetap berlangsung sepanjang hayat manusia.

Ada tiga alasan penting mengapa pendidikan menjadi yang terpenting dalam kehidupan manusia. Pertama, pendidikan berlangsung lama

*Magister Agama lulusan Program Pascasarjana UIN Alauddin Makassar ini adalah kandidiat doktor bidang pendidikan Islam pada almamater yang sama. Saat ini ia sedang menjabat sebagai Pembantu Dekan Bidang Akademik Fakultas Tarbiyah dan Keguruan UIN Alauddin Makassar. 
dan terus menerus. Kedua, pendidikan merupakan salah satu pranata sosial penting yang direncanakan matang oleh suatu masyarakat. Ketiga, pendidikan bertalian erat dengan pembentukan watak dan kepribadian manusia.

Fakta-fakta historis menunjukkan bahwa kemajuan bangsa-bangsa modern sangat ditentukan oleh sejauhmana kualitas pendidikan masyarakat. Proses pemanusiaan manusia ternyata sangat ditentukan oleh kontinuitas pendidikan yang dijalani manusia, baik dalam kapasitas sebagai objek pendidikan maupun subjek pendidikan. Di sini terlihat bahwa manusia dan pendidikan ada dan tumbuh serta berkembang secara paralel. Semakin maju peradaban manusia semakin maju dan berkembang pula kualitas pendidikannya; begitu pula sebaliknya, semakin maju dan berkembang kualitas pendidikan, semakin maju pula peradaban manusia. Dalam kaitan ini manusia dikenal sebagai makhluk yang memiliki aspek pedagogis, yaitu makhluk yang harus dididik. ${ }^{2}$ Biasa pula manusia disebut sebagai homo educandum.

Tulisan ini mencoba menguraikan aspek pedagogis manusia dalam pandangan Islam maupun Barat.

\section{MANUSIA DALAM BERBAGAI PANDANGAN}

Pergumulan nilai tentang siapa itu manusia, dari mana ia berasal, sedang apa kini, dan hendak kemana berakhir, telah berjalan ribuan tahun yang telah silam.

Makhluk hidup yang bernama manusia telah menjadi pembicaraan yang unik, yang tidak pernah ada ujungnya, sehingga timbullah konsepsi manusia yang beragam menurut sudut tinjauan dan persepsinya masingmasing.

Menurut pandangan kaum materialisme 3 manusia hanya tersusun dari tubuh kasar, manusia hanya merupakan susunan-susunan bendawi, partikel-partikel materi yang menjadi satu. Menurut pandangan mereka hidup manusia hanya sekali saja, setelah manusia mati habislah atau berakhirlah riwayat hidup manusia tanpa ada kelanjutan hidup berikutnya. Tidak ada kehidupan akhirat yang ada di dalamnya pahala sebagai imbalan terhadap perbuatan baik, dan siksa sebagai balasan dari perbuatan dosa dan tercela. Kebahagiaan menurut pandangan kaum ini hanya dapat dicapai di dunia dengan mengumpulkan materi sebanyak mungkin. Sehingga tujuan hidup mereka adalah materi, maka mereka menghalalkan segala cara. Akhirnya mereka membuat onar, fitnah maupun kerusakan. Karena bagi mereka tidak ada hari kebangkitan (hisab). Inilah kelompok yang digambarkan Allah dalam Q.S. al-Mu'minun, ayat 37, yang artinya: 
Kehidupan itu tidak lain hanyalah kehidupan kita di dunia ini. Kita mati dan kita hidup dan sekali-kali tidak akan dibangkitkan kembali. ${ }^{4}$

Kalau kaum materialisme berpendapat manusia hanya sekedar rangkaian materi atau fisik, maka menurut kelompok intelektualisme, manusia tersusun dari jasmani dan rohani. Akan tetapi, konteks rohani menurut mereka adalah akal, itulah sebabnya mereka berpendapat kebahagian hanya akan didapat selain dengan materi, juga dengan mengembangkan intelek semaksimal mungkin. Kelompok inipun tidak mempercayai adanya hari kiamat sebagai hari pembalasan amal baik dan amal buruk. Hidup dan mati menurut mereka hanya sekali saja. Bahkan menurut mereka manusia mati atau binasa tidak ada yang mematikan atau membinasakan kecuali al-Dahri, masa atau nature ${ }^{5}$. Allah memperkenalkan kelompok ini dalam firmannya dalam Q.S. al-Jātsiah, ayat 24 yang terjemahannya sebagai berikut:

Dan mereka berkata: kehidupan ini tidak lain hanyalah kehidupan di dunia saja, kita mati dan kita hidup dan tidak ada yang membinasakan kita selain masa, dan mereka sekali-kali tidak mempunyai pengetahuan tentang itu, mereka tidak lain hanya menduga-duga saja. ${ }^{6}$

Abd. Muin Salim ${ }^{7}$ ketika menguraikan fitrah manusia dalam Alquran memperkenalkan tiga istilah yang biasa dipakai Alquran berkaitan dengan penamaan manusia. Pertama: al-Insan, al-Isn, al-Nas, Anasiy, dan Insiy. Kata ini mengandung konsep manusia sebagai mahkluk yang memiliki sifat keramahan dan kemampuan mengetahui yang sangat tinggi. Atau dengan ungkapan lisan manusia sebagi makhluk sosial dan makhluk kultural. Kedua: al-Basyar: mengisyaratkan manusia sebagai mempunyai, menanggapi dan menyatakan emosinya dalam komunikasi dengan sesamanya, juga manusia mempunyai kedudukan sebagai "penguasa bumi" dan hanya akan memperoleh kegembiraan (kebahagiaan) jika ia melaksanakan tugasnya itu. Ketiga: Bani Adam dan Zurriyat Adam; kedua istilah ini merujuk kepada manusia karena adanya dan mendapat penghormatan dari Allah.

Penggunaan kedua kata tersebut di atas bermakna atau memberi kesan kesejarahan dalam konsep manusia, dan bahwa manusia mempunyai satu asal. 8 Kedua kata itupun memberi arti konsep keragaman manusia yang terdiri atas berbagai warna dan bangsa. Dengan begitu, kedua istilah di atas relevan dengan konsep politik, sebab konsep-konsep tersebut merupakan basis bagi prinsip musyawarah. Dalam bagian lain filosof seperti Socrates ${ }^{9}$ mengatakan bahwa manusia adalah Zoon Politicon, yaitu hewan yang bermasyarakat, hewan yang menerima kenyataan adanya kehadiran manusia dalam berbagi kelompok dan adanya potensi manusia untuk mengkomunikasikan hubungan antar sesama manusia. 
Musa Asy'ari ketika membahas manusia dengan memakai pendekatan semantik, menyebutkan bahwa Alquran memperkenalkan dua kata kunci untuk memahami manusia secara komprehensif. Kedua kata kunci tersebut adalah: al-Insān yang bentuk jamaknya al-Nās, memiliki arti melihat, mengetahui dan minta izin. Atas dasar ini, kata tersebut mengandung petunjuk adanya kaitan substansial antara manusia dengan kemampuan penalaran, yakni dengan penalaran itu manusia dapat mengambil pelajaran dari apa yang dilihatnya, ia dapat mengetahui apa yang benar dan apa yang salah, dan terdorong untuk meminta izin dalam rangka menggunakan sesuatu yang bukan miliknya. Pengertian ini menunjukkan dengan jelas adanya potensi manusia untuk dapat didik.

Kata kunci yang kedua adalah kata al-basyar jamak dari kata basyarah, yang artinya permukaan kulit kepala, wajah, dan tubuh manusia. Olehnya itu, kata mubāsyarah diartikan mulāmasah yang artinya persentuhan antara kulit laki-laki dengan kulit perempuan.

Menurut Asy-Syāti ${ }^{10}$ pemakaian kata basyar di beberapa tempat dalam Alquran seluruhnya memberikan pengertian anak Adam yang bisa makan dan berjalan di pasar-pasar, dan di dalam pasar itu mereka saling bertemu atas dasar persamaan. Dengan demikian, kata basyar selalu mengacu kepada manusia dari aspek lahiriyah, mempunyai bentuk tubuh yang sama, makan dan minum dari bahan yang sama yang ada dalam alam ini, dan karena pertambahan usia maka kondisi tubuhnya akan menurun, menjadi tua dan akhirnya akan mati.

Ada dua hal yang dapat dicermati dari uraian bahwa manusia dalam pengertian basyar, tergantung sepenuhnya pada alam, pertumbuhan dan perkembangan fisiknya bergantung pada apa yang dimakan dan diminumnya. Sedangkan manusia dalam pengertian insan mempunyai pertumbuhan dan perkembangan yang sepenuhnya tergantung pada kebudayaan, termasuk ke dalamnya adalah pendidikan. Dengan demikian, pemahaman kedua kata tersebut berdimensi: insan digunakan untuk menunjuk pada kualitas pemikiran dan kesadaran, sedangkan basyar digunakan untuk menunjuk pada dimensi alamiahnya, yang menjadi ciri pokok manusia pada umumnya, seperti makan, minum, dan kemudian mati.

Menurut Langeveld 11 , manusia adalah suatu realitas yang harus merealisasikan dirinya. Manusia memahami dirinya sebagai subyek sekaligus obyek. Manusia adalah pribadi yang harus mengangkat dirinya ke taraf insani (monodualisme). Ia mengalami proses bertindak, berbuat membangun dirinya menjadi pribadi dewasa yang susila. Pribadi dewasa susila memiliki karakteristik: 
1. Memahami, mengerti, dan mencintai dirinya (individualisme).

2. Memahami, mengerti, dan mencintai orang lain (sosialitas).

3. Menyadari, memiliki norma kesusilaan dan nilai-nilai kemanusiaan, dan

4. Bertindak, berbuat sesuai dengan norma kesusilaan, nilai-nilai hidup atas tanggung jawab sendiri, demi kebahagian dirinya dan kebahagian masyarakat, orang lain (moralitas).

Pemikiran M. J. Langeveld di atas, sebenarnya sama dan sebangun dengan pengertian insan dan basyar yang dimaknai secara semantik dari teks-teks Alquran yang mengindikasikan manusia memiliki berbagai aspek, seperti: individualitas, sosialitas, kultural, bahkan moralitas yang kesemuanya menempatkan manusia pada dimensi yang berbeda dengan makhluk Allah yang lain, termasuk hewan, yang walaupun oleh Socrates menyebutnya sebagai zoon politicon, hewan yang bermasyarakat, atau Max Schaller, 12 menyebutkan sebagai das kranke tier, hewan yang sakit.

Charles Darwin ${ }^{13}$ dengan teori evolusinya telah menerangkan bahwa manusia bukanlah suatu proses perubahan dari primat atau kera kemudian menjadi manusia. Proses evolusi Darwin akhirnya terhempas oleh mata rantai yang hilang, the missing link, dan tidak menemukan bukti-bukti yang kuat adanya perubahan dari primat atau kera menjadi manusia. Kera tetap kera, sejenis hewan, makhluk Tuhan yang derajatnya jauh di bawah manusia, yang diciptakan Tuhan sebagai makhluk yang mulia.

Menurut Alexis Carrel ${ }^{14}$, manusia adalah makhluk misterius, karena derajat keterpisahan manusia dari dirinya berbanding terbalik dengan perhatiannya yang demikian tinggi terhadap dunia yang ada di luar dirinya. Pendapat ini menunjukkan betapa sulitnya memahami manusia secara tuntas dan menyeluruh. Sehingga setiap kali seseorang selesai memahami manusia dari suatu aspek, maka muncul pula aspek yang lainnya yang belum ia bahas.

Berbagai literatur yang membahas tentang hakekat manusia dalam alam semesta ini selalu dihubungkan dengan konsep kekhalifaan manusia di muka bumi. Quraish Shihab ${ }^{15}$ ketika membahas tentang hal ini mengatakan bahwa kata khalifah dalam berbagai bentuk mengartikan kekuasaan pada manusia dalam dua bentuk, yaitu kekuasaan dalam bidang politik yang dikhususkan untuk nabi-nabi dan tidak digunakan untuk manusia pada umumnya. Dan kekuasaan yang bukan saja di bidang politik, tetapi juga dalam berbagai kehidupan yang dimiliki manusia pada umumnya.

Walaupun manusia makhluk yang diberikan kekuasaan berlebih oleh Allah, tetapi menurut Quraish Shihab diperlukan sikap moral dan etika yang harus ditegakkan dalam melaksanakan fungsi kekhalifaan tersebut, sehingga manusia harus sadari bahwa hubungannya dengan alam atau 
dengan sesama manusia bukan sebagai hubungan penakluk dan yang ditaklukkan atau hubungan hamba dengan tuan, tetapi hubungan kebersamaan dalam ketundukan kepada Allah. Karena walaupun manusia mampu mengelola (menguasai) bumi, tetapi hal tersebut bukan akibat kekuatan atau kekuasaan yang dimilikinya, melainkan akibat Tuhan menundukkannya kepada manusia.

Menurut Abuddin Nata16, Alquran memberikan petunjuk bahwa untuk menjadi khalifah, seseorang perlu memahami persyaratan yang bersifat teknis dan keterampilan, memiliki kemampuan yang bersifat konseptual yang dihasilkan melalui pendidikan. Artinya, manusia sebagai khalifah perlu memiliki pendidikan yang cukup.

Kedudukan lainnya dari manusia di alam ini sering diangkat oleh para pakar, adalah manusia sebagai hamba ('abd). Musa Asy'ari17 ketika membahas hal ini mengatakan bahwa esensi 'abd adalah ketaatan, ketundukan dan kepatuhan yang semuanya itu layak diberikan pada Tuhan. Dengan demikian kedudukan manusia di alam raya ini di samping sebagai khalifah yang memiliki kekuasaan untuk mengelola alam dengan menggunakan segenap daya dan potensi yang dimilikinya, juga sekaligus sebagai 'abd, yaitu seluruh usaha dan aktivitasnya itu hanya dilaksanakan dalam rangka ibadah kepada Allah. Untuk dapat melaksanakan fungsi kekhalifahan dan ibadah dengan baik, maka manusia perlu diberikan pendidikan, pengajaran, pengalaman, keterampilan, teknologi dan sarana pendukung lainnya. Ini menunjukkan bahwa konsep kekhalifahan dan ibadah dalam Alquran erat kaitannya dengan pendidikan. Manusia yang dapat melaksanakan fungsi-fungsi tersebut itulah yang diharapkan muncul dari kegiatan pendidikan.

\section{MANUSIA DAN KEBUTUHANNYA TERHADAP PENDIDIKAN}

Jika diakui bahwa Adam as. adalah penghulu umat manusia, maka itu berarti adanya pengakuan bahwa umur pendidikan setua umur manusia. Bahwa pendidikan itu telah ada sejak adanya manusia di permukaan bumi.

Dalam Alquran didapati informasi tentang bagaimana Allah berkenan mengajarkan Adam berbagai nama (ilmu pengetahuan), bahkan pengetahuan Adam mengenai nama-nama tersebut telah menjadi keunggulan komparatif manusia dari makhluk-makhluk lain. ${ }^{18}$ Dari sini pula dapat dipahami bahwa manusia sangat membutuhkan pendidikan. Tanpa pendidikan manusia tidak memiliki arti apa-apa. Oleh karena itu, Allah berkenan melengkapi manusia dengan pendengaran, penglihatan dengan aneka hati,19 agar manusia dapat mengkomunikasikan dengan potensi- 
potensi lain sehingga ia dapat menjadi manusia yang dapat dididik maupun mendidik (pedagogik).

Menurut Umar Tirtarahardja 20 , manusia lahir telah dikaruniai dimensi hakekat manusia yang masih dalam wujud potensi; belum teraktualisasi menjadi wujud aktualisasi. Dari kondisi potensi menjadi wujud aktualisasi terdapat rentang proses yang mengandung pendidikan untuk berperan dalam memberikan jasanya. Seseorang yang dilahirkan dengan bakat seni, misalnya, memerlukan pendidikan untuk proses menjadi seniman terkenal.

Setiap manusia lahir dikaruniai naluri, yaitu dorongan-dorongan yang alami (dorongan makan, seks, mempertahankan diri dan lain-lain). Jika seandainya manusia dapat hidup hanya dengan naluri, maka tidak ada bedanya dengan binatang. Hanya melalui pendidikan status binatang itu dapat diubah ke arah status manusia. Di sinilah hakekat dari pesan Rasulullah bahwa manusia telah dilahirkan dengan membawa fitrah, berupa potensi-potensi yang perlu dikembangkan oleh kedua orangtuanya agar anak dapat tumbuh dan berkembang sesuai dengan fitrah-nya itu. Kesalahan orangtua dalam mendidik akan mengakibatkan terjadinya apa yang dikenal condisi sin cuanon bagi kelanjutan pertumbuhan dan perkembangan peserta didik. Itulah sebabnya, Al-Gazali ${ }^{21}$ mengatakan, melatih atau mendidik anak-anak adalah suatu hal yang penting, karena anak adalah amanat bagi kedua orangtuanya. Hati anak suci bagaikan mutiara cemerlang, bersih dari segala ukiran serta gambaran, ia mampu menerima segala yang diukirkan atasnya dan condong kepada segala yang dicondongkan kepadanya. Adanya pendidikan awal dalam keluarga dan berlangsung pendidikan seumur hidup (life long education) bagi manusia diakui oleh berbagai tokoh muslim maupun barat, seperti oleh Ivan Paulou (1849-1936) di Rusia dan Edward Z. Thorndike (1874-1949) di Amerika Serikat, yang melahirkan konsep clasical conditioning dan operant condition yang memandang bahwa anak didik adalah generator of information.

Perbincangan selanjutnya tentang manusia sebagai makhluk yang dapat dididik (pedagogik) melahirkan berbagai pandangan menyangkut dominasi pendidikan terhadap pertumbuhan dan perkembangan anak. Dalam dunia pendidikan dikenal berbagai aliran pendidikan yang dapat dikategorikan sebagai aliran yang berprasangka tentang kurangnya peranan pendidikan dalam perkembangan anak. Aliran ini biasanya disebut aliran pesimisme, dan sebaliknya aliran yang sangat optimis terhadap peranan pendidikan dalam perkembangan jiwa anak.

\section{Aliran Pesimisme dalam Pendidikan}

Aliran ini bertolak dari leibnitzion tradition yang menekankan kemampuan dalam diri anak, sehingga faktor lingkungan, termasuk faktor pendi- 
dikan, kurang berpengaruh terhadap perkembangan anak. Aliran ini berpendapat bahwa anak tumbuh dalam kemampuan diri yang bersifat kodrati, sedangkan pengaruh dari faktor luar lingkungan dianggap tidak memberikan bekas pada pertumbuhan anak.

Tokoh aliran ini adalah Schopenhauer, filosof Jerman (1788-1880), 22 berpendapat bahwa bayi itu lahir sudah dengan pembawaan baik dan pembawaan buruk, karena itu hasil pendidikan ditentukan oleh pembawaan sejak lahir. Berdasarkan pandangan ini, maka keberhasilan pendidikan ditentukan oleh anak itu sendiri, yang jahat akan menjadi jahat dan yang baik akan menjadi baik. Pendidikan yang tidak sesuai dengan bakat dan pembawaan anak tidak akan berguna untuk perkembangan anak itu sendiri.

Sesuai dengan makna asal katanya natie yang berarti terlahir, 23 aliran ini berpendapat lingkungan sekitar tidak ada artinya sebab lingkungan tidak berdaya dalam mempengaruhi perkembangan anak. mereka berpendapat sifat baik dan buruk yang dibawa sejak lahir tidak akan dapat diubah oleh kekuatan luar.

Psikolog Austria, ${ }^{24} \mathrm{H}$. Rohracher, mengemukakan manusia adalah produk dari hukum proses alamiah yang berlangsung sebelumnya, yang bukan buah dari pekerjaannya dan bukan pula menurut keinginannya. Pendapat yang sama juga dikemukakan oleh L. Szondi, dorongan dan tingkah laku sosial dan intelektual ditentukan sepenuhnya oleh faktorfaktor yang diturunkan, sebagai "nasib", yang menentukan seseorang.

Dengan demikian, aliran pedagogisch pesimisme atau optimisme yang bersifat natifisme berpendapat bahwa pendidikan tidak mempunyai kekuatan. Pendidikan hanya merubah lapisan permukaan atau kulit dari watak anak didik. Sedangkan lapisan paling dalam dari kepribadian anak tidak perlu ditentukan. Apa yang patut dihargai dari pendidikan tidak lebih dari sekedar memoles lapisan permukaan peradaban dan tingkah laku sosial.

Sekarang muncul aliran humanistic psychology dari aliran Nativisme yang dipelopori oleh carl R. Rogers ${ }^{25}$ yang mengakui pentingnya belajar, tetapi pengalaman dalam belajar itu sangat ditentukan oleh kemampuan memberi kepada apa yang dialaminya itu. Dengan kata lain pengalaman belajar ditentukan oleh internal frame of reference yang dimiliki anak. Sebuah pemikiran yang mendekati pemikiran aliran Empirisme.

\section{Aliran Optimisme dalam Pendidikan}

Aliran optimisme dalam pendidikan dikenal dengan nama empirisme. Berbeda dengan nativisme, aliran ini berpendapat bahwa pengaruh atau 
faktor-faktor dari luar saja yang berpengaruh pada perkembangan anak.

Aliran empirisme bertolak dari Lockean Traditional yang mementingkan simulasi eksternal dalam perkembangan manusia, dan menyatakan bahwa perkembangan anak tergantung kepada lingkungan, sedangkan pembawaan tidak dipentingkan. Pengalaman yang diperoleh anak dalam kehidupan sehari-hari didapat dari dunia sekitarnya yang berupa stimulanstimulan. Stimulan berasal dari alam bebas maupun diciptakan oleh orang dewasa dalam bentuk program pendidikan. Tokoh perintis aliran ini adalah seorang filosof Inggris bernama John Locke (1632-1704), yang mengembangkan teori tabula rasa ${ }^{26}$, yakni anak lahir di dunia bagaikan kertas putih. Pengalaman empirik yang diperoleh dari lingkungan akan berpengaruh besar dalam perkembangan anak. Menurut pandangan empirisme, pendidikan memegang peranan yang sangat penting, sebab pendidikan dapat menyediakan lingkungan pendidikan kepada anak dan akan diterima oleh anak sebagai pengalaman-pengalaman yang sesuai dengan tujuan pendidikan.

\section{Aliran Teori Konvergensi}

Perintis aliran ini adalah William Stern (1871-1939), sorang ahli pendidikan bangsa Jerman. Seperti ingin menengahi dua pemikiran terdahulu yang terkesan bertentangan. Aliran ini mengakui adanya pembawaan baik dan buruk yang dibawa anak sejak lahir, begitu pula mengakui peran yang dimainkan oleh lingkungan maupun pendidikan. Menurut aliran ini, dalam proses perkembangan anak, baik faktor pembawaan maupun faktor lingkungan sama-sama mempunyai peran yang sangat penting. Bakat yang dibawa sejak lahir tidak akan berkembang dengan baik tanpa adanya dukungan lingkungan yang sesuai dengan perkembangan bakat itu. Sebaliknya, lingkungan yang baik tidak dapat menghasilkan perkembangan anak yang optimal kalau memang pada diri anak tidak terdapat bakat yang diperlukan untuk itu. Jadi, pembawaan dan lingkungan merupakan dua garis konvergensi (memusat ke satu titik) dan kedua-duanya sangat penting bagi perkembangan.

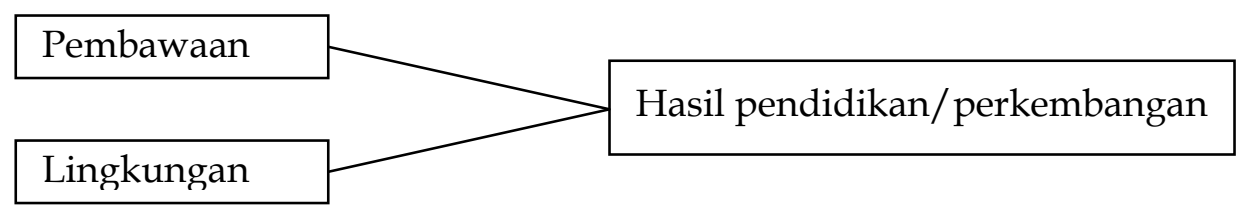

Menurut teori konvergensi:

- Pendidikan mungkin untuk dilaksanakan.

- Pendidikan diartikan sebagai pertolongan yang diberikan lingkungan 
kepada peserta didik untuk mengembangankan potensi-potensi yang baik dan mencegah berkembangnya potensi yang kurang baik.

- Yang membatasi hasil pendidikan adalah pembawaan dan juga lingkungan. ${ }^{27}$

\section{ISLAM DAN ALIRAN-ALIRAN DALAM PENDIDIKAN}

Sebagai sebuah ajaran yang diyakini kesempurnaanya, maka Islam melalui ajaran-ajarannya telah menginformasikan dan mengkonfirmasikan kepada umatnya tentang berbagai faktor yang dominan dan mempengaruhi pendidikan.

Dalam kaitannya dengan pendapat aliran nativisme yang mengembangkan potensi "dasar" yang dominan dalam perkembangan anak, maka Islam melalui ajaran-ajarannya telah memperkenalkan adanya ajaran tentang potensi "dasar" atau bawaan.

Ajaran-ajaran ini dapat dilihat antara lain dalam:

- Q.S. al-Nahl (16): 78.

- Q.S. al-Rum (30): 30.

- Hadis Rasulullah tentang manusia yang dilahirkan dengan membawa potensi dasar (fitrah).

- Hadis Rasulullah tentang selektif di dalam memiliki keturunan karena keturunan berpotensi mempengaruhi perkembangan anak.

- Hadis Rasulullah tentang adanya penetapan bahwa anak sejak dalam rahim ibu.

- Dan lain-lain.

Menyangkut adanya pengaruh lingkungan atau "ajar" terhadap perkembangan anak, Allah maupun Rasul-Nya telah mengajarkan bahwa:

- Perkembangan seseorang ditentukan oleh hasil usaha, lihat Q.S. alNajam (53): 39.

- Yang merubah nasib manusia adalah manusia sendiri. Lihat Q.S. alRa'ad (13): 11. Dalam pengertian yang sama dapat dilihat juga Q.S. alBaqarah (2): 286.

- Hadis Nabi tentang peranan orangtua terhadap perkembangan anak.

Dengan demikian, Islam lebih cenderung kepada aliran konvergensi, yang mengakui adanya peranan "dasar" atau bawaan dan "ajar", atau lingkungan pendidikan dalam proses perkembangan anak.

Menurut Zakiah Daradjat, ${ }^{28}$ meskipun Alquran dan Hadis tidak secara tegas menentukan tentang faktor lingkungan dan keturunan sebagai faktor pokok yang mempengaruhi pertumbuhan insan, tetapi dapat dipahami dari yang tersirat dalam ajaran tersebut tentang adanya dua warisan yang berpengaruh, yaitu: 
- Warisan alami atau fitrah (internal) yang dipindahkan oleh jaringanjaringan benih.

- Warisan sosial (external) yang dipindahkan oleh faktor di luar diri (unitunit sosial, terutama keluarga, media yang berperan dalam bagian ini adalah pancaindera, akal, tradisi, serta jenis interaksi sosial yang beraneka ragam).

Menurut Ibnu Taimiyah, ${ }^{29}$ manusia dikaruniai tabiat atau kecenderungan beribadah hanya kepada Allah. Namun, seseorang tidak akan dapat mencapai perkembangan kecenderungan tauhidnya itu dengan sempurna kecuali melalui pendidikan dan pengajaran. Ibnu Maskawaih ${ }^{30}$ mengakui potensi atau tabiat manusia yang dibawa sejak lahir yang salah satu contohnya adalah tabiat memelihara diri, yang dapat dikembangkan melalui pendidikan yang dilakukan oleh lingkungan sekolah. Lingkungan pemerintahan, dan lingkungan rumah tangga.

Berbagai pendapat di atas lebih mempertegas komitmen Islam tentang adanya pengaruh "dasar" bawaan dan "ajar" lingkungan dalam perkembangan anak.

\section{PENUTUP}

Dari berbagai uraian di atas, dapat disimpulkan bahwa:

1. Manusia adalah makhluk Allah yang diciptakan dengan berbagai kelebihan dari makhluk-makhluk yang lain. Salah satu kelebihannya adalah dapat dididik atau dapat menerima pendidikan, karena itu manusia disebut homo educabil, homo educandum atau makhluk yang beraspek pedagogis. Suatu spesies yang dapat menerima pendidikan, bahkan berperan dalam pendidikan.

2. Manusia dalam berbagai pandangan disebut sebagai makhluk sosial, kultural, bahkan sebagai penguasa bumi. Perkembangan dimensi sosial, kultural dan power hanya akan dapat dilakukan melalui pendidikan. Hal ini berarti manusia membutuhkan pendidikan bagi perkembangan dirinya.

3. Para pemikir pendidikan memperkenalkan tiga aliran pendidikan, yang mempengaruhi perkembangan manusia, yaitu, nativisme, empirisme dan konvergensi. Namun, dalam perkembangnnya konvergensi lebih diterima sebagai sebuah konsep pendidikan karena sesuai dengan fakta-fakta empirik, edukatif, dan nas-nas ajaran agama.

\section{CATATAN AKHIR}

1. Lihat umpamanya dalam Q.S. al-Nahl (16) ayat 78. 
2. Lihat H. M. Said, Ilmu Pendidikan, Bandung: Alumni, 1985, h. 5.

3. Lihat A. Nur Alam Bakri, "Manusia: Fisik, Akal, dan Kalbu", dalam Muhrab, Bulletin \& Kumpulan Ceramah, IC, MSK No. 5/XI/85, Jakarta: Masjid Agung Sunda Kelapa, h. 4 dan 5.

4. Kehidupan dan kematian yang dimaksudkan dalam ayat ini menggambarkan sebuah pemaknaan bahwa lahir dan meninggal adalah suatu proses yang sangat natural (alamiah) yang terjadi secara lumrah. Tidak ada kaitannya dengan perhitungan amal di hari akhirat. Lihat, catatan kaki no. 101, pada Yayasan Penyelenggara Penterjemah/Penafsir al-Qur'an, al-Qur'an dan Terjemahnya, Jakarta: PT. Intermasa, 1993, h. 530.

5. Lihat A. Nur Alam Bakri, "Manusia: Fisik, Akal dan Kalbu”, dlm Muhrab, h. 5.

6. Lihat Yayasan Penyelenggara Penterjemah/Penafsir al-Qur'an, al-Qur'an dan Terjemahnya, h. 818.

7. Lihat Abd. Muin Salim, Fitrah Manusia dalam al-Qur'an, Ujung Pandang: Lembaga Studi Kebudayaan Islam (LKSI), 1990, h. 1-13.

8. Menurut Sastraprateja, manusia adalah makhluk yang historis. Hakikat manusia sendiri adalah suatu sejarah, suatu peristiwa, yang bukan sematamata datang. Hakekat manusia hanya dapat dilihat dalam perjalanan sejarahnya, dalam sejarah bangsa Indonesia. Lihat, M. Sastraprateja, Manusia Multi Dimensional Sebuah Renungan Filsafat, Jakarta: Gramedia, 1982, h. ix-x.

9. Lihat Umar Tirtarahardja dan La Sula, Pengantar Pendidikan, Jakarta: Rineka Cipta, cet. I, 2000, h. 3.

10. Lihat Aisyah 'Abd al-Rahman binti Asy-Syāti, Al-Maqāl fi al-Insān Dirāsah Qur'āniyah, Mesir: Dar al-Ma'arif, 1996, h. 13-14.

11. Lihat Langeveld, dalam Ivens Taulaini, dkk., Dasar-dasar Ilmu Pendidikan, Jakarta: Gramedia Pustaka Utama, 1996, cet. III, h. 20.

12. Lihat Umar Tirtarahardja dan La Sula, Pengantar Pendidikan, h. 3.

13. Lihat Umar Tirtarahardja dan La Sula, Pengantar Pendidikan, h. 3.

14. Lihat Alexis Carrel dalam Abuddin Nata, Filsafat Pendidikan Islam, jilid I, Jakarta: Logos Wacana Ilmu, cet. I. 1997, h. 29.

15. Lihat Quraish Shihab, Membumikan al-Qur'an, Bandung: Mizan, 1992, cet. II, h. $156 \mathrm{~s} / \mathrm{d} 158$.

16. Lihat Abuddin Nata, Filsafat Pendidikan Islam, h. 39.

17. Lihat Musa Asy'ari, Manusia Pembentuk Kebudayaan dalam al-Qur'an, Yogyakarta: Lembaga Studi Filsafat Islam, 1992, cet. I, h. 1 dan 2.

18. Ayat 31 s/d 34 surah al-Baqarah dapat menjadi rujukan untuk mendeteksi adanya proses belajar mengajar yang dilakukan Allah terhadap hambanya Adam (manusia), yang dalam ayat-ayat tersebut dapat pula dimaknai adanya keunggulan manusia dari makhluk yang lain karena berilmu. Kata, Usjudu li Adam, sujudlah kepada Adam, dapat dimaknai sebagai perantara untuk memberi pengakuan terhadap eksistensi Adam sebagai makhluk yang berilmu yang telah lulus dalam proses belajar mengajar, (falammā anbaahum bi asmāihim), yang tidak dapat dilakukan oleh malaikat (mewakili makhluk selain manusia), subhānaka lā 'ilma lanāa illā mā 'allamtanā.

19. Lihat Yayasan Penyelenggara Penterjemah/Penafsir al-Qur'an, al-Qur'an dan Terjemahnya, h. 413.

20. Lihat Umar Tirtarahardja dan La Sula, Pengantar Pendidikan, h. 24. 
21. Lihat H. M Arifin, Hubungan Timbal Balik Pendidikan Agama di Lingkungan Sekolah dan Keluarga, Jakarta: Bulan Bintang, cet. II, h. 75.

22. Lihat Zakiyah Daradjat, dkk., Ilmu Pendidikan Islam, Jakarta: Bumi Aksara, cet. V, 2004, h. 51. Bandingkan dengan Umar Tirtarahardja dan La Sula, Pengantar Pendidikan, h. 196, bandingkan pula dengan H. M. Arifin, Hubungan Timbal Balik Pendidikan Agama di Lingkungan Sekolah dan Keluarga, h. 51.

23. Lihat Zakiyah Daradjat, dkk., Ilmu Pendidikan Islam, h. 51.

24. Lihat Zakiyah Daradjat, dkk., Ilmu Pendidikan Islam, h. 51.

25. Lihat Umar Tirtarahardja dan La Sula, Pengantar Pendidikan, h. 196.

26. Lihat Zakiyah Daradjat, dkk., Ilmu Pendidikan Islam, h. 52 dan 53.

27. Lihat Umar Tirtarahardja dan La Sula, Pengantar Pendidikan, h. 199.

28. Lihat Zakiyah Daradjat, dkk., Ilmu Pendidikan Islam, h. 56 dan 57.

29. Lihat Abuddin Nata, Pemikiran Para Tokoh Pendidikan Islam, Jakarta: Raja Grafindo Persada, cet. II, 2001, h. 141 dan 142.

30. Lihat Abuddin Nata, Pemikiran Para Tokoh Pendidikan Islam, h. 22.

\section{DAFTAR PUSTAKA}

Arifin, H. M., Hubungan Timbal Balik Pendidikan Agama di Lingkungan Sekolah dan Keluarga, Jakarta: Bulan Bintang.

Asy'ari, Musa, Manusia Pembentuk Kebudayaan dalam al-Qur'an, Yogyakarta: Lembaga Studi Filsafat Islam, 1992.

Bakri, A. Nur Alam, "Manusia Fisik, Akal, dan Kalbu", dalam Muhrab, Bulletin \& Kumpulan Ceramah, IC, MSK No. 5/XI/85, Jakarta, Masjid Agung Sunda Kelapa.

Carrel, Alexis, dalam Abuddin Nata, Filsafat Pendidikan Islam, jilid I, Jakarta: Logos Wacana Ilmu, cet. I. 1997.

Daradjat, Zakiyah, dkk., Ilmu Pendidikan Islam, Jakarta: Bumi Aksara, cet. V, 2004.

Departemen Agama RI., al-Qur'an dan Terjemahnya, Jakarta: Yayasan Penyelenggara Penterjemah/Penafsiran al-Qur'an, PT. Intermasa, 1993.

Langeveld, dalam Ivens Taulaini, dkk., Dasar-dasar Ilmu Pendidikan, Jakarta: Gramedia Pustaka Utama, 1996.

Nata, Abuddin, Pemikiran Para Tokoh Pendidikan Islam, Jakarta, Raja Grafindo Persada, cet. II, 2001.

Said, H. M., Ilmu Pendidikan, Bandung: Alumni, 1985, h. 5.

Salim, Abd. Muin, Fitrah Manusia dalam al-Qur'an, Ujung Pandang, Lembaga Studi Kebudayaan Islam (LKSI), 1990.

Sastraprateja, M., Manusia Multi Dimensional Sebuah Renungan Filsafat, Jakarta: Gramedia, 1982.

Shihab, Quraish, Membumikan al-Qur'an, Bandung: Mizan, 1992.

Asy-Syāti bin Aisyah, 'Abd al-Rahman. Al-Maqāl fi al-Insān Dirāsah Qur'āniyah, Mesir: Dar al-Ma'arif, 1996.

Tirtarahardja, Umar dan La Sula, Pengantar Pendidikan, Jakarta: Rineka Cipta, 2000. 